\title{
Trauma és identitás kérdései perinatális testvérvesztést átéltek narratíváiban
}

\author{
Issues of trauma and identity in surviving siblings' narratives on \\ perinatal loss
}

\section{BORNEMISZA ÁGNES}

Bornemisza Ágnes: Pécsi Tudományegyetem, Egészségtudományi Kar, Ápolástudományi, Alapozó Egészségtudományi és Védőnői Intézet; agnes.bornemisza@etk.pte.hu Agnes Bornemisza: University of Pécs, Faculty of Health Sciences, Department of Health Visiting and Prevention; agnes.bornemisza@etk.pte.hu

\begin{abstract}
Absztrakt
„A gyász annak az átérzése, hogy az elveszített személy része saját énünknek; ehhez társul annak a kínos érzése, hogy a halált saját részünk elveszítéseként éljük át" (Kovácsné Török et al., 1995, p. 243). A transzgenerációs trauma vonulata gyakran megjelenik a perinatális veszteséget átélt családok körében. Ennek a válságos élethelyzetnek a narratívája néma marad, a családtagok őrzik a titkot, mert a veszteség fájdalma megoszthatatlannak tünik számukra. A tanulmány - rövid szakirodalmi áttekintést követően - a perinatális veszteség következtében kialakuló identitásproblémákat a túlélő testvérek narratívái elemzésének segítségével mutatja be. A szerző felhívja a figyelmet a téma további kutatásának fontosságára.
\end{abstract}

Kulcsszavak: perinatális halálozás, identitás, transzgenerációs trauma

\begin{abstract}
Grief is an experience that the lost person is part of our own self; accompanied by the embarrassing feeling of experiencing death as a loss of a part of our own self (Kovácsné Török et al., 1995). The trajectory of transgenerational trauma often appears among families who have experienced perinatal loss, as the event is unbearable, its narrative is silent, and family members keep the secret because the pain of loss cannot be shared. This study presents the identity problems resulting from perinatal loss through a literature review and a brief analysis on siblings' narratives who experienced perinatal loss. The author argues for the necessity of further research on the topic.
\end{abstract}

Keywords: perinatal loss, identity, transgenerational trauma

„, Semmi nincs lelkileg eröteljesebb hatással a gyermekre, mint a szülök meg nem élt élete." (Jung, 1995, p. 5)

\section{Identitás és trauma}

Szondi Lipót (1893-1986) magyar származású pszichiáter sorsanalízisét a XX. század mélylélektani irányzatai közé soroljuk. Az emberi sors és hivatás alakulása, 
determináltságának kérdésköre pályafutása kezdetétől felkeltette Szondi Lipót érdeklődését. Páciensei élettörténeteinek tanulmányozása vezette el elméletének megfogalmazásához. Freud és Jung munkásságát továbbgondolva, Szondi a személyes és kollektív tudattalan mellett a családi tudattalan fogalmát alkotja meg. Ezzel az élet sorsfordulóinál megszülető választások meghatározó szerepét írja le - a családi felmenők sorsának tükrében. Szondi meglátása szerint sorsunkat döntéseink, választásaink alakítják, és ezekben nagy szerepet kapnak azok a rég meghalt rokonaink, akiknek életét már nem is ismerjük.

Az egészséges identitással jellemezhető személy a családi tudattalan által felkínált lehetőségek közül (kényszerü sors) szabadon választhat, megteremtve ezzel saját, szabad sorsát, egyéni életútját (Gyöngyösiné Kiss \& Oláh, 2007).

\section{A korai trauma hatása az identitás fejlődésére}

Az egészséges személyiségfejlődés során kialakulnak azok az alapstruktúrák, amelyekre az identitásunkat építjük. Ezáltal az egyén számára a traumatikus események is átélhetővé és feldolgozhatóvá válnak, így ideális esetben nem okoznak maradandó törést az életben. Az élettörténeti események között - a feldolgozás révén - folytonosság alakul ki, az érzések között összefüggés jön létre, és maga a narratíva is egységes, átadható lesz (Bakó \& Zana, 2021).

Az emberi kapcsolatokat nagymértékben befolyásolja a környezet nyitottsága, visszatükrözőképessége, ez pedig alapfeltétele a jó személyiségfejlődésnek, és a mentalizációnak (Winnicott, 1953, 1960, 1999). Ezáltal épülhet ki az ősbizalom (Erikson, 1963), amelynek korai átélése a krízis, trauma során is biztos kapaszkodó, és amely a megfelelő feldolgozás során tovább erősödik. A traumafeldolgozás során így segítség az egyén belső erőforrása, és természetesen az olyan külső erőforrások, mint a társas kapcsolatok és a megfelelő társadalmi-kulturális közeg.

A korai életévekben az identitás alapjául szolgáló szelf még kialakulóban van, sérülékeny. A személyiségfejlődés e szenzitív szakaszában bekövetkező traumatikus események különösen rombolóan hathatnak, segítség nélkül a személyiség nem tud újraépülni.

A jó kötődéssel jellemezhető anya-gyermek kapcsolatban a szülő minta, vonatkoztatási pont. A kapcsolat biztonságos közeget jelent a csecsemő számára, aki ezáltal lesz képes felépíteni énmagját. Ennek birtokában és tudatában lesz képes változni, rugalmasan alkalmazkodni a külvilághoz. Az érzelmileg stabil anya ezt az alkalmazkodást jól tudja segíteni, ezáltal a gyermek a későbbi életévek során egyre inkább képessé válik önálló személyiségként müködni. Ez a folyamat optimálisan olyan lélektani térben tud létrejönni, ahol a szülő és a gyerek is szabadon mozog, és ez a lélektani tér egyszerre közös és egyéni. Ez adja az egészséges anya-gyermek kapcsolat mi élményét, amely állandó, de egyben dinamikus is, az egyéni fejlödésre, alkalmazkodásra teret adó.

\section{A traumatizált családban felnövekvő gyermek identitása}

Traumatizált családok túlélőiben rendszerint nem tud kialakulni az egészséges szelf. Az elviselt trauma következtében az én bizonyos részei lehasadnak, és őrzik a feldolgozatlan emlékeket. A töredékes szelfrész integrálatlansága, hiánya oda vezet, hogy az egyén pótolni próbálja a leszakadt részt. Így például egy gyermek születésével az anya a gyerek 
önazonosságát sajátjaként értelmezi és „használja”. A sérült családi légkörben a feldolgozatlan trauma emlékei nem tudnak integrálódni sem az anya, sem a csecsemő számára. Az anya nem képes az ún. konténerfunkcióját sem ellátni, azaz segíteni gyermekét a megterhelő tapasztalatokkal, érzelmekkel való megbirkózásban. Így tulajdonképpen lehetetlenné teszi a csecsemő felé irányuló hétköznapi ingerek értelmezését, feldolgozását. A csecsemő magára marad, frusztrálttá válik, a világ fenyegető lesz számára a sok emészthetetlen élmény következtében. A folyamatot tovább nehezíti, hogy az eredeti viszonyt megfordítva, az anya „használja” a csecsemőt saját feldolgozatlan élményeinek konténereként. Ez az összetett mechanizmus a gyerek számára nem kínál lehetőséget az érzelemszabályozás és az önnyugtatási képesség megtanulására. A kicsi gyermek a feldolgozatlan élményeket a külvilágba, vagy egy lezárt belső térbe üzi. Ezekben a családokban a feldolgozatlan, fenyegető élmények, emlékek adják az alaphangulatot, amely nem a reális világot jeleníti meg. A gyermek számára azonban ez a fenyegetettség válik alapértelmezetté. A családi atmoszféra által éli meg a feldolgozatlan trauma élményeit, amelyhez neki közvetlen módon semmi köze, nem érti, miért él fenyegetettségben, csak ennek jelenvalóságát érzi. A gyereknek az a szerepe ezekben a családokban, hogy megjelenítse a szülő számára a boldogságot, a reményt, értelmet adjon a szülö életének. A csecsemőnek azonban nincs esélye az egészséges szelf kialakítására, hiszen az anya nem tud önálló személyként rátekinteni. Létrejön a „, mi atmoszféra”, amely a kölcsönös érzelemmegélésen át fenntartja és erősíti a torz élmény fennmaradását. A mi-szelfböl azonban nincs kilépés egyik fél számára sem. A szülő számára a gyerek énjének fejlődése, önállósodása fenyegetően hat, hiszen elveszíti a „megtalált” szelf részét. A gyerek számára pedig a ,, mi atmoszféra” jelenti a biztonságot, a folyamatosságot. A traumatikus emlékeket hordozó családokba született csecsemő számára az adhat esélyt, ha más, kötődésre alkalmas személy is jelen van a korai életévekben. Az elég jól müködő korai kapcsolatok teret adnak az egészséges énfejlődésnek, ámbár a párhuzamos gondviselői jelenlét miatt ezek a szelfrészek nagyon sérülékenyek lehetnek (Bakó \& Zana, 2021; Balogh et al., 2021).

\section{A saját jogon meg nem született gyerekek}

Azok a gyerekek, akik elöl a meg nem született, vagy korán meghalt testvérük létét eltitkolják, nem képesek teljesen saját életet élni. A tudat mélyén hordozott küldetésük az, hogy a szülőknek ,életet adjanak”, azaz megjelenítsék a szülők lehasított, elfeledett énrészét. Hivatásukat azonban nem tudják betölteni, mert a feldolgozatlan veszteség következtében a szülőnek a meghalt gyermek marad a tökéletes. Ezek a gyermekek nem az elvesztett testvérre emlékeztetnek, hanem ők maguk az emlékek. A gyermek és a szülö is a gyász feldolgozásának hiányában sérült szelffel él. Ennek a lehasított szelfnek a feldolgozatlan tartalma tartja életben az elvesztett testvért, és ez adja a létjogosultságát az életben lévő gyermeknek. Ebben az atmoszférában lesz megosztható az eddig meg nem osztott élmény, amelyben aztán generációk osztoznak, és ez a légkör az, amelyben kapcsolódni tudnak.

A legifjabb generáció tagjai összefüggő élettörténet hiányában hallgatást, néma, vagy szakadozott narratívákat őriznek. A „fantomtraumák” eltemetett események függelékei, amelyek nem saját, szuverén történetek, hanem a korábbi generációk által megélt, de fel nem dolgozott eseményekből származnak. A „fantomok” olyan lehasított énrészekből kerülnek elő, amelyek tartalma több generáció óta feltáratlan, elbeszélhetetlen (Bakó \& Zana, 2021; Balogh et al., 2021). 


\section{Perinatális veszteséget átélt testvérek narratíváinak vizsgálata}

\section{A vizsgálat föbb kérdései}

Az empirikus vizsgálat fó kérdése az volt, hogy milyen hosszú távú következményekkel szembesülnek azok a személyek, akik gyermekként átélték testvérük elvesztését. Hogyan hat ez identitásfejlődésükre, mennyiben befolyásolja felnőtt életüket? Jelen vannak-e az elbeszélt történetekben a transzgenerációs traumákat átélő gyermekek fentiekben bemutatott közös élményei?

\section{Módszer}

Félig strukturált mélyinterjúkat készítettem olyan személyekkel, akiknek a családjában perinatális haláleset történt. Ez a téma különösen megterhelő az interjúalanyok számára, így az etikai alapelveket tiszteletben tartva - rájuk bíztam, mennyit kívánnak megosztani történetükből. A beszélgetést követően mindegyikük számára biztosított volt további tanácsadás igénybevétele. A felkeresett 50 válaszadó közül 30 személlyel sikerült elkészíteni az interjút, ebből 20 interjú az, ami tematikus elemzés céljaira felhasználható.

\section{1. táblázat}

A válaszadók demográfiai adatai

\begin{tabular}{|c|c|c|c|c|}
\hline \multicolumn{3}{|c|}{ Perinatális veszteséget átélt testvérek } & \multirow{2}{*}{ Interjú hossza } & \multirow{2}{*}{ Testvér születéskori állapota } \\
\hline Név & Életkor & Nem & & \\
\hline A. & 41 év & $\mathrm{F}$ & 40 perc & $\mathrm{kb} .40$ órát élt \\
\hline D. & 31 év & $\mathrm{F}$ & 13 perc & 1 hétig élt \\
\hline B. & 30 év & $\mathrm{F}$ & 12 perc & halva született \\
\hline Má. & 23 év & $\mathrm{F}$ & 20 perc & halva született \\
\hline Mis. & 27 év & $\mathrm{F}$ & 14 perc & 1 hétig élt \\
\hline L.G. & 47 év & $\mathrm{F}$ & 15 perc & 5 napig élt \\
\hline L.P. & 53 év & $\mathrm{F}$ & 14 perc & halva született \\
\hline S. & 35 év & $\mathrm{F}$ & 31 perc & halva született \\
\hline E. & 23 év & $\mathrm{N}$ & 45 perc & 40 órát élt \\
\hline Vi. & 28 év & $\mathrm{N}$ & 15 perc & halva született \\
\hline Mi. & 47 év & $\mathrm{N}$ & $12: 22$ perc & halva született \\
\hline $\mathrm{R}$. & 34 év & $\mathrm{N}$ & $28: 22$ perc & halva született \\
\hline G. & 30 év & $\mathrm{N}$ & 20 perc & halva született \\
\hline Fi. & 26 év & $\mathrm{N}$ & $28: 22$ perc & halva született \\
\hline I. & 63 év & $\mathrm{N}$ & 15 perc & halva született \\
\hline L. & 50 év & $\mathrm{N}$ & 38 perc & halva született \\
\hline Zs. & 42 év & $\mathrm{N}$ & 45 perc & halva született \\
\hline N. & 25 év & $\mathrm{N}$ & 25 perc & 3 napot élt \\
\hline Va. & 54év & $\mathrm{N}$ & 23perc & halva született \\
\hline $\mathrm{Fa}$. & 38 év & $\mathrm{N}$ & 12 perc & halva született \\
\hline
\end{tabular}


A vizsgálatba bevont válaszadók mindegyike vagy közvetlenül, vagy közvetetten tapasztalta a veszteség családja életére gyakorolt hatását. Először minden interjúalany a következő kérésre válaszolt: „Kérem, mesélje el testvére elvesztésének történetét!”. Ezután szabadon elmondhatták tapasztalataikat. A későbbi kérdések között szerepelt a szülöi gyász, a veszteség hatása a túlélö testvér életére, a transzgenerációs hatások és a lehetséges megküzdési stratégiák. Kérdezőként nyitott voltam minden felmerülő új témára a beszélgetés során. Valamennyi interjúalany hozzájárult a hangfelvételhez, a szövegek szó szerinti leírásához, az adatok elemzéséhez és az eredmények közzétételéhez. Az adatok feldolgozása ebben a vizsgálatban deduktív tematikus tartalomelemzéssel történt, azaz a szakirodalmi áttekintésben meghatározott témákat vizsgáltam.

\section{Eredmények}

Az interjúk során jól nyomon követhetővé válik az identitás sérülése a családi néma, vagy töredezett narratíva következtében.

\section{Néma történetek}

A két visszaemlékező töredezett narratívája rávilágít lelkiállapotukra, felnőttként is hordozott szorongásukra:

„érthető, hogy szüleim nem mondtak el mindent teljes részletességgel, csak azt tudtam, hogy valami nagyon nagy baj van, és... én rettegtem attól" (A)

„Hanem én kicsi gyerekként kíváncsian rákérdeztem, hogy hol van a pocakja, hol van a kisbaba. És akkor és erre mondott valamit, hogy az angyalokkal van, vagy valami ilyesmit. Erre én nem emlékszem személy szerint, csak ezt így mondták nekem többször, hogy valahogy így, valahogy így tudtam meg, hogy mi történt és aztán... igazából szerintem nagyon sokáig nem beszéltünk róla otthon, vagy nem emlékszem rá, bár nem volt tabu téma, tehát nem gondolom, hogy direkt [torokköszörülés] titkolták volna, nem hozták szóba.” (R)

\section{Helyettesitö gyermekek}

A beszélgetések során fény derült az „emlékmécses-gyermekek” vagy „helyettesítő gyermekek" által megélt élményekre is. Vi. teljesen azonosul a fiú szereppel, melyet szülei „elvárnak” tőle, azaz éli a kényszersors adta lehetőségek szerint a gyermekéveit:

„Szóval és akkor mindig egy kicsit azt éreztem, hogy voltak anyukámnak ilyen beszólásai, hogy ha már nem vagyok fiú, akkor..." (Vi)

E. esetében a szerepek összezavarodása, az alacsony önértékelés központi téma. A narratívában a saját életre való jogosultság kérdőjeleződik meg:

„Az öcsémre is azt mondtam, hogy én... én csak a prototípus vagyok, de ő a tökéletes. És én szerintem ő is, biztos vagyok benne, hogy jobb lett volna, mint én, sokkal. Ö biztos nem hozott volna annyi csalódást, ő annyival jobb lett volna, tényleg... mint én. És nagy ritkán mikor nézem ezt a képet, ezt a párat, a fejtámlát, ezt a sírkövet... nem is sírkő, csak az a fa, és, hogy oda van írva a neve. Nagyon sokszor egyébként úgy láttam, mintha az enyém lenne ott és... és hát nyilván többször megfordult a fejemben... Én hát azért nagyon korán érkeztem, anya 21 volt, hogy lehet, hogy jobb lett volna, ha nem ragaszkodnak ennyire ehhez, hogy minél 
hamarabb legyen gyerek és ez így... és akkor ez így... én nem érkeztem volna, és akkor jöhetett volna ö." (E)

G. esetében az emlékmécses-gyermek képével találkozunk. G. neve nem lesz felvállalható a család, majd saját maga számára sem. A név hozzájárul identitásunkhoz, identitásunk pedig önbecsülésünket adja (Balogh et al., 2021):

„És [sóhaj] hát ugye amiatt is [sóhaj] nehezített az én szerepem ebben a kérdésben, mert hogy azt a nevet kaptam, amit ez a baba kapott, vagy kapott volna. Ez ilyen tisztázatlan. Ha így ráutal valaki a családban, akkor az én nevemen hívja öt, merthogy így ezt kapta volna, de ez így nem teljesen van tisztázva, hogy ők most végül is adták neki ezt a nevet hivatalosan, vagy csak akarták, vagy én nem is tudom. Úgyhogy ez abszolút egy ilyen szerepzavar, és az biztos, hogy a szüleimben is az volt, mert elég hamar kaptam egy becenevet, és onnantól kezdve igazából mindenki így hívott." (G)

\section{Mi-atmoszféra, konténerfunkció}

Az alábbi három visszaemlékező a „mi-atmoszféra” torzító szerepéről beszél. L. hét testvérét veszíti el a perinatális időszak különböző fázisaiban. A családi atmoszféra más traumatikus események miatt is kripta jellegü, a „mi-atmoszféra” átszövi a családi kapcsolatokat. „A traumatörténetek épp ezért különlegesek, hiszen az őseim szenvedése bennem is tovább él" (Balogh et al., 202, p. 11). Az alábbi szövegek tanúsága szerint a gyermek lesz a traumatizáló élmény érzelmi súlyának kijelölt hordozója:

„Aki elöttem valószínü két évvel született, ő volt az a fiú, aki halva jött világra. Ezt később édesanyám többször „vérfagyasztóan” mesélte el. Hogyan dobták születés után egy vödörbe és ö hallotta hogyan koppan.” (L)

E. nehéz érzésekkel küzd, ám ezeket az érzéseket nem a sajátjaként, hanem a szülei fájdalmaként azonosítja:

„hogyha megnézem ezt a képet és megnézem ezt... és igazából és igazából a fájdalmam nem az enyém, hanem amit a szüleim átéltek. Az ő fájdalmuk az enyém valójában.” (E)

I. számára „életprogrammá”, női identitásának részévé válik a szülés, születés kínja, amit az édesanyjával megélt szoros „mi élmény”, egyfajta anyai örökség tart életben:

„És olyan kínja volt, hogy csavargatta ezeket a rácsokat. Akkor ez engem már gyerekként megrázott..., hogy hogy nem is nagyon tudtam semmit a szülésröl, tudtam, hogy ez egy fájdalmas dolog, és hogy mi lesz akkor majd, ha nekem is kell szülni és ilyen kín... kínokat kell átélni. Nekem így magáról az embergyerek születéséről az első élményem, hogy a testvéremet az anyukám a kínok kínjával hozta világra.” (I)

\section{Következtetések, javaslatok}

Ebben a kutatásban a transzgenerációs traumák szelffejlődésre gyakorolt hatásait egy különleges csoport esetében vizsgáltuk. A perinatális veszteséget túlélő testvérekre viszonylag kevés kutatás irányul. A fenti interjúrészletek jól mutatják, hogy a család feldolgozatlan gyásza mély hatással van a túlélő testvérek életére, és ezek a hatások a transzgenerációs 
traumák jelenségvilágát tükrözik. Ugyanakkor fontos kiemelni, hogy ez az elemzés nem jeleníti meg a vizsgált terület, a testvérgyász más vonatkozásait, és a válaszadók sem reprezentálják a testvérgyászt átélő személyek összességét. Ez etikai szempontok miatt sem volna lehetséges, hiszen senki nem kényszeríthető arra, hogy traumatikus élményeit egy kutatás keretei között megossza.

Vajon tényleg hatalmunkban áll megválasztani sorsunkat, vagy kénytelenek vagyunk őseink nyomdokaiban járni? Magunkban hordozzuk azokat a felmenőinket, akiket már személyesen nem is ismertünk. Ezek az énünk zárványiban élő fantomok kísérik mindennapjainkat, de ha tudunk az öket körülvevő történetekről, és beszélünk is ezekröl, tudatosíthatjuk a családi sorsot, és dönthetünk a saját életutunk felöl. Gyakran sok veszteséggel kell szembenéznünk, hosszú időt és sok kitartást igényel a gyász feldolgozása, de ezáltal lesz valódi és élhető a mi történetünk, a mi életutunk, a mi szabad döntésünk. Most már mi teremtjük meg a családi történeteket, de családi fantomok, kriptahangulat nélkül. Utódaink már elbeszélhető, integrált, teljes narratívákat vihetnek tovább, amelyekben az ősök múltja felvállalható, elmesélhető (Balogh et al., 2021).

A kicsi gyerekek szívesen hallgatják azokat a történeteket, amelyek róluk, szüleikröl, nagyszüleikröl szólnak. Ezáltal lesz számukra is eleven az a múlt, amely kihat a jelen hétköznapjaira. A későbbi életévekben, amikor felnőtt identitásuk kialakulóban van, elengedhetetlen, hogy tudják, értsék, honnan jöttek. Lehet, hogy csak ekkor kerül sor a családi anekdoták, az elfeledett titkok felelevenítésére. A családi történetek az örömök, az ünnepek, de a bánat, a veszteségek, titkok hordozói is. A meghitt családi beszélgetésekben új fényt kap minden, az öröm fényesebb, de a veszteség, a fájdalmas titok is felvállalható, elmondható.

Ennek azonban feltétele a súlyosan traumatizáló élethelyzetekben nyújtott segítség. A perinatális veszteség kapcsán ennek elmulasztása több generáció életét nehezítheti meg. Ha a családi „kripta” sok vagy súlyos „fantomot” tartalmaz, ez az út nem járható egyedül. Szaksegítséget kell kérnünk, hogy integrálhassuk felnőtt énünkbe a múlt történéseit, és a trauma átélésével érettebbé, bölcsebbé, az életet értékelni tudó személlyé válhassunk.

\section{Irodalom}

Bakó, T., \& Zana, K. (2021). A transzgenerációs trauma és terápiája. Medicina Kiadó.

Balogh, K., Bárdos, K., Békési, T., Hardy, J., Koltai, M., Korbuly, Á., \& Tóth, B. (2021). Transzgenerációs történetek: Örökül kapott traumák és feldolgozásuk. HVG Könyvek.

Erikson, E. H. (1991). Az életciklus. Az identitás epigenezise. In E. H. Erikson, A fiatal Luther és más irások (pp. 437-496). Gondolat Kiadó.

Gyöngyösiné Kiss, E., \& Oláh, A. (Eds.) (2007). Vázlatok a személyiségröl: A személyiséglélektan alapvető irányzatainak tükrében. Új Mandátum Könyvkiadó.

Jung, C. G. (1995). Gondolatok az apáról az anyáról és a gyermekről. Kossuth Kiadó.

Kovácsné Török, Zs., \& Szeverényi, P. (1996). A gyász pszichológiai vonatkozásai II. Perinatális gyász. Magyar Pszichológiai Szemle, 52(36), 67-79.

Winnicott, W. D. (1953). Transitional objects and transitional phenomena: A study of the first not-me possession. International Journal of Psycho-Analysis, 34(2), 89-97.

Winnicott, W. D. (1960). The theory of the parent-infant relationship. International Journal of Psycho-Analysis, 41, 585-595.

Winnicott, W. D. (1999). Játszás és valóság. Animula Kiadó. 